\title{
Impacts of Off-Road Vehicles on Infiltration and Sediment Production of Two Desert Soils
}

\author{
R.E. ECKERT, JR., M.K. WOOD, W.H. BLACKBURN, AND F.F. PETERSON
}

\begin{abstract}
Impacts of motorcycle and 4-wheel drive truck traffic on infiltration rate and sediment production were evaluated on two desert soils. Infiltration was similar for both soils; however, more sediment was produced from a surface with exposed mineral soil than from a gravel-mulched surface. Infiltration was 3 to 13 times greater on the coppice soil beneath shrubs than on interspace soil between shrubs, but sedimentation was 10 to 20 times greater on interspace soil. Infiltration was less and sediment yield was greater after soil was disturbed by vehicular traffic, and after reformation of the surface crust, particularly on interspace soil. High sediment production from interspace soil was attrihuted to reduced infiltration after 10 minutes. The soil then became saturated and unstable, was dispersed by raindrop impact, and particles were carried in runoff water for the remaining 20 minutes of the test period. Coppice soil had a high infiltration rate for the entire test period and did not become saturated. In addition, the high organic matter and aggregate stability of coppice soil prevented soil movement, though some runoff occurred.
\end{abstract}

Off-road vehicle (ORV) traffic is a major factor in the management of recreational lands (Bury et al. 1976). The consensus among scientists is that ORV's damage fragile desert habitats and that much more information is needed before official sanction is given for their continued use over extensive areas (Stebbins 1974). Although formalized research may not be necessary to establish that damage does occur. it would help to quantify the extent of damage in response to variables such as soil. moisture content, slope, and kind of traffic. Some of this information can be obtained from research on the effects of soil disturbance and compaction on the hydrological properties and

During the research. authors were range scientist. U.S. Department of Agriculture. SIA-AR. Rencuable Resource Center. University of Nevada 920 Valley Road. Reno 89512: graduate research assistant: assistant professor of range and watershed management: and profersor of plant. soil. and water sciences, Univ. of Nevada. Reno. NV 89512. Wood's and Blackburn's current address is the Range Science Department. Texas A\&M linicresity. College Station 77843.

The work represents cooperative investigations of the U.S. Dep. Agr.. SEA-AR, and the Agr. Exp. Sta. C'niv, of Nevada. Reno. Journal Series No. 400. The research was veperred in part by the Bureau of Land Management. U.S. Dep. Interior.

1.antuscript receised September 5. 1978 responses of agricultural lands (American Society of Agricultural Engineers 1971) and of forest and rangelands (Lull 1959). Many of the site-specific effects, however, are unknown. The objective of this study was to evaluate the initial impacts of two types of ORV's on the infiltration rate and sediment production characteristics of two desert soils in response to simulated rainfall.

\section{Description of Study Areas and Methods}

The study was conducted on two sites in southern Nevada. Blue Diamond has a vegetative composition typical of the creosote bush (Larrea tridentata) type with a shrub crown cover of $8.3 \%$. Soil is a loamy-skeletal, carbonatic, thermic, shallow, typic Paleorthid. Crystal Springs has a vegetative composition typical of the blackbrush (Coleogyne ramosissimum) type with a shrub crown cover of $25.5 \%$. Soil is a loamy skeletal, mixed, thermic, shallow, typic Durorthid. Two major types of surface soils are found on each site: the "coppice soil " on the low, small dunes under shrubs and the mostly barren "interspace soil" between shrubs. The A horizons of the coppice soil are weakly subangular blocky structured, gravelly, sandy loams that are soft and relatively permeable. The interspace soils have gravel pavements. These are either a single-layer embedded in the mineral soil, or several pebbles thick, forming a gravel-mulch over the mineral soil. The 2 to $6 \mathrm{~cm}$ thick loamy, crusted A horizon is massive, has vesicular pores, and is broken into $8-15 \mathrm{~cm}$ diameter polygons. The crusted interspace soil slakes and disperses readily when wetted. The coppice-type soil covers 14.2 and $34.7 \%$ of the surface at the Blue Diamond and Crystal Springs sites, respectively, while interspace soil covers 85.8 and $65.3 \%$, respectively.

Motorcycle (50 passes), truck (20 passes), and control treatments were imposed in August, 1975, at both locations, and in January, 1976 , at Blue Diamond and in April, 1976, at Crystal Springs. Different dates were used in 1976 in order to obtain similar surfacesoil moisture conditions on the two sites at time of treatment Motorcycles were trail-bikes $(350 \mathrm{lb}$ ) and the truck was a $3 / 4$-ton pickup operated in 4-wheel drive. Vehicles were generally "hot rodded" up and down slopes of 2 to $5 \%$ at about $30 \mathrm{~km} / \mathrm{hr}$. Tracks were made in a straight line so that both coppice and interspace soils were disturbed. A verage track depth on the motorcycle treatment on interspace soil was $1.0 \mathrm{~cm}$ and $1.5 \mathrm{~cm}$ on coppice soil. Average track depth on the 
truck treatment was $1.1 \mathrm{~cm}$ on interspace soil and $2.0 \mathrm{~cm}$ on coppice soil. Soil moisture measured by the neutron surface probe was between -8 and -15 bars (air-dry soil) at time of treatment at both locations and in both surface soils. Shrubs were cut at ground level and removed from the coppice area. Runoff plots $\left(0.14 \mathrm{~m}^{2}\right)$ were placed in five replications of each soil on each treatment. Simulated rainfall was applied at the rate of $3.4 \mathrm{~cm} / \mathrm{hr}$ for 30 minutes with a mobile infiltrometer (Blackburn et al. 1974). This rainfall rate represents a return frequency of about 4 years at Blue Diamond and of about 15 years at Crystal Springs (Miller et al. 1973).

Volume of runoff was measured every 5 minutes for 30 minutes and sediment was accumulated over 30 minutes. Five-minute and terminal infiltration rates were calculated from runoff data and are expressed in $\mathrm{cm} / \mathrm{hr}$. Sediment production is expressed in $\mathrm{kg} / \mathrm{ha}$. After the first simulated rainfall event plots were covered with plastic and the soil crust was allowed to dry and reform. This process required less than a month in the hot part of the year and several months in the cool part of the year. After the crust had reformed, a second simulated rainfall event was applied to the same plots as previously described and runoff and sediment data were collected. The effects of crust condition were evaluated because, in spite of the return intervals calculated from a short period of records from valley weather stations, high intensity rainfall events can reoccur on upland locations over a much shorter time.

\section{Results and Discussion}

Infiltration was similar on both soils; however, sediment production was greater at Blue Diamond (Table 1). The charac teristic gravel-embedded pavement in a silt loam vesicular A horizon at Blue Diamond suggests a greater potential for suspended sediment in runoff water than does the gravel-mulch surface over a vesicular, sandy loam A horizon at Crystal Springs.

Type of surface soil had the greatest effect on infiltration and sediment production. Infiltration was from 3 to 13 times greater on coppice soil and sediment production was 10 to 20 times greater on interspace soil. Again, soil characteristics appear to be the determining factor. For example, coppice soils have a nonvesicular surface with a well-aggregated, fine subangular blocky structure that transmits water rapidly (Lull 1964). The aggregated structure is also more resistant to dispersion and movement in runoff (Storey et al. 1964). The A horizons of

Table 1. Mean terminal infiltration rate $(\mathrm{cm} / \mathrm{hr})$ and sediment production $(\mathrm{kg} / \mathrm{ha})$ in response to variables in 1975 and 1976 . Simulated precipitation was applied at the rate of $3.4 \mathrm{~cm} / \mathrm{hr}$ for 30 minutes.

\begin{tabular}{|c|c|c|c|c|}
\hline \multirow[b]{2}{*}{ Variable } & \multicolumn{2}{|c|}{ Terminal infiltration ${ }^{1}$} & \multicolumn{2}{|c|}{ Sediment production $^{1}$} \\
\hline & 1975 & 1976 & 1975 & 1976 \\
\hline \multicolumn{5}{|l|}{ Study site } \\
\hline Blue Diamond & $1.9 \mathrm{a}$ & $1.4 \mathrm{a}$ & $222 \mathrm{a}$ & $457 \mathrm{a}$ \\
\hline Crystal Springs & $1.8 \mathrm{a}$ & $1.5 \mathrm{a}$ & $116 \mathrm{~b}$ & $109 \mathrm{~b}$ \\
\hline \multicolumn{5}{|l|}{ Soil } \\
\hline Coppice & $2.7 \mathrm{a}$ & $2.6 \mathrm{a}$ & $33 \mathrm{~b}$ & $30 \mathrm{~b}$ \\
\hline Interspace & $0.9 \mathrm{~b}$ & $0.2 \mathrm{~b}$ & $306 \mathrm{a}$ & 537 a \\
\hline \multicolumn{5}{|l|}{ Vehicle treatment } \\
\hline Motorcycle & $1.5 \mathrm{~b}$ & $1.3 \mathrm{~b}$ & $192 \mathrm{a}$ & $237 a b$ \\
\hline Truck & $1.6 \mathrm{~b}$ & $1.2 \mathrm{~b}$ & $273 \mathrm{a}$ & 451 a \\
\hline Control & $2.2 \mathrm{a}$ & $1.7 \mathrm{a}$ & $42 \mathrm{~b}$ & $126 \mathrm{~b}$ \\
\hline \multicolumn{5}{|l|}{ Crust condition } \\
\hline Disturbed & $2.1 \mathrm{a}$ & $1.5 \mathrm{a}$ & $147 \mathrm{a}$ & $282 \mathrm{a}$ \\
\hline Reformed & $1.5 \mathrm{~b}$ & $1.3 \mathrm{~b}$ & $192 a$ & $284 a$ \\
\hline
\end{tabular}

${ }^{1}$ Infiltration and sediment means within year and variable followed by different letters are significantly different at the 0.05 level of probability as determined by Duncan's multiple range test. interspace soils are vesicular and massive. Water moves slowly through this surface, saturation occurs quickly, the silty, weakly structured soils becomes unstable, and fine-textured particles are susceptible to dispersion and movement in runoff (Blackburn 1975; Rose 1966).

Infiltration rates on the motorcycle and truck treatments were similar to each other and less than controls (Table 1). Sediment production was also similar for both vehicle treatments and generally was greater than controls. Average infiltration rates were lower after crust reformation and average sediment production was unchanged (Table 1). The crust condition $\times$ soil interaction showed that the infiltration rate of the coppice was reduced from 3.0 to $2.4 \mathrm{~cm} / \mathrm{hr}$, and that of the interspace was reduced from 1.4 to $0.5 \mathrm{~cm} / \mathrm{hr}$ after crust reformation. Although the main effects showed no difference in sediment production between crust conditions, the interaction showed that more sediment $(356 \mathrm{~kg} / \mathrm{ha})$ was produced after interspace soil crust reformed than when first disturbed $(265 \mathrm{~kg} / \mathrm{ha})$. Sediment production from coppice soil was the same between crust conditions. The crust condition $\times$ vehicle interaction showed the infiltration was reduced from 2.1 to $1.1 \mathrm{~cm} / \mathrm{hr}$ and sediment was increased from 187 to $359 \mathrm{~kg} / \mathrm{ha}$ as the result of crust reformation after the truck treatment. Most of the reduction in infiltration rate and the increase in sediment production occurred after the interspace soil crust had reformed. The lowest infiltration rate $(0.2 \mathrm{~cm} / \mathrm{hr})$ and the highest sediment production $(1,338 \mathrm{~kg} / \mathrm{ha})$ occurred at Blue Diamond on reformed crust after the truck treatment.

The vehicle treatment $\times$ soil interaction (Table 2 ) shows that the already low infiltration rate on interspace soil is changed little by treatment compared with the control. The high infiltration rate on the coppice soil, however, generally is reduced by vehicular treatment, particularly by the truck treatment. In contrast, vehicular treatments did not increase the sediment from coppice soil compared with the control, but greatly increased the sediment load on the interspace soil, particularly for the truck treatment. The stable structure of the coppice soil evidently resists dispersement and movement even when infiltration is reduced and runoff is increased. The rapidly saturated and poorly aggregated interspace soil is more easily dispersed and moved after disturbance, but is generally stable when undisturbed (Stebbins 1975) in spite of low infiltration and high runoff rates.

Table 2. Mean terminal infiltration rate $(\mathrm{cm} / \mathrm{hr})$ and sediment production (kg/ha) on coppice and interspace soils in response to traffice treatments in 1975 and 1976. Simulated precipitation was applied at a rate of 3.4 $\mathrm{cm} / \mathrm{hr}$ for 30 minutes.

\begin{tabular}{|c|c|c|c|c|}
\hline \multirow[b]{2}{*}{ Treatment and Soil } & \multicolumn{2}{|c|}{ Terminal infiltration' } & \multicolumn{2}{|c|}{ Sediment production } \\
\hline & 1975 & 1976 & 1975 & 1976 \\
\hline \multicolumn{5}{|l|}{ Motorcycle } \\
\hline Coppice & $2.8 \mathrm{a}$ & $2.5 \mathrm{~b}$ & $9 b$ & $36 \mathrm{~cd}$ \\
\hline Interspace & $0.2 \mathrm{~d}$ & $0.2 \mathrm{c}$ & $376 \mathrm{a}$ & $509 \mathrm{~b}$ \\
\hline \multicolumn{5}{|l|}{ Truck } \\
\hline Coppice & $2.0 \mathrm{~b}$ & $2.2 \mathrm{~b}$ & $85 \mathrm{~b}$ & $45 \mathrm{~cd}$ \\
\hline Interspace & $1.1 \mathrm{c}$ & $0.1 \mathrm{c}$ & $461 \mathrm{a}$ & $857 \mathrm{a}$ \\
\hline \multicolumn{5}{|l|}{ Control } \\
\hline Coppice & $3.2 \mathrm{a}$ & $3.1 \mathrm{a}$ & $4 b$ & $9 \mathrm{~cd}$ \\
\hline Interspace & $1.4 \mathrm{c}$ & $0.4 \mathrm{c}$ & $81 b$ & $244 c$ \\
\hline
\end{tabular}

1 Infiltration and sediment means within year followed by different letters are significantly different at the 0.05 level of probahility as determined by Duncan`s multiple range test. 


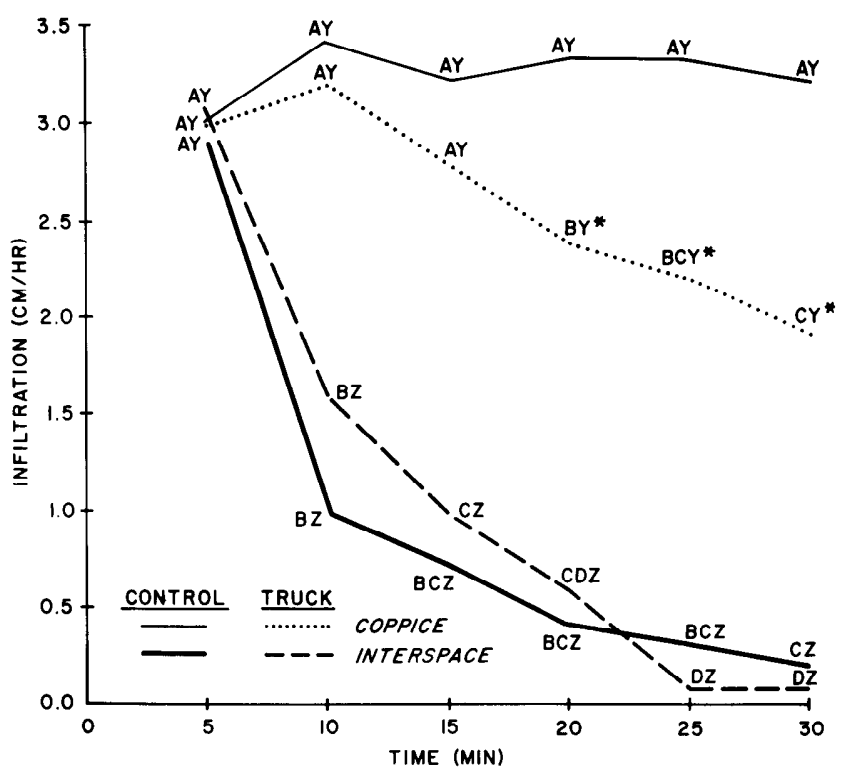

Fig. 1. Infiltration curves for the coppice and gravel-embedded interspace soils on the truck and control treatments at Blue Diamond. Significance of differences over time on each soil within a treatment (letters $A-D$ ); between soils within a treatment (letters $Y-Z)$; and on each soil between treatments (asterisk) was determined by Duncan's multiple range test at the 5\% level of probability.

The impacts of vehicular traffic are the result of soil damage due to shear and compaction (Harrison 1976). Shear damage would result in destruction of the protective desert pavement, powdering of fine soil material, and filling the cracks between surface polygons. All these physical disturbances would increase the potential for water and wind erosion. Compaction increases bulk density and decreases pore space (Lull 1959). Wilshire and Nakata (1976) used penetrometer data to show that soil compaction was the dominant consequence of intense motorcycle use. Davidson and Fox (1974) showed that bulk density and macropore space decreased with compaction by vehicular traffic. Changes in these characteristics probably decrease both the amount of water a soil can hold and permeability so that water runoff is increased. With increased runoff, the soil powdered by shear effects would be susceptible to movement along the track. Since water will continue to collect and run in the track, the cumulative effects of ORV impacts may not be known for years or decades after the original disturbance (Vollmer et al. 1976).

The time $\times$ vehicle $\times$ soil interaction indicated different infiltration responses at the two locations. At Blue Diamond (Fig. 1), infiltration rate of the coppice soil for the truck treatment was similar for the first 15 minutes, then decreased during each of the three succeeding 5-minute periods. In contrast, infiltration of the coppice soil for the control did not decrease over the 30-minute period. Infiltration of the interspace soil on both the truck and control treatments was similar. Both decreased rapidly after 10 minutes, then decreased more slowly for the remaining 20 minutes. Infiltration rate of both soils on the truck and control treatments was similar after the initial 5 minutes, then infiltration on both treatments was significantly greater on the coppice soil than on the interspace soil after each 5-minute period. Infiltration on the coppice soil was similar for the truck and control treatments for the first 15 minutes. For the remainder of the trial, infiltration was less for the truck treatment. The coppice soil showed a similar response to time on the truck and control treatments at Crystal Springs

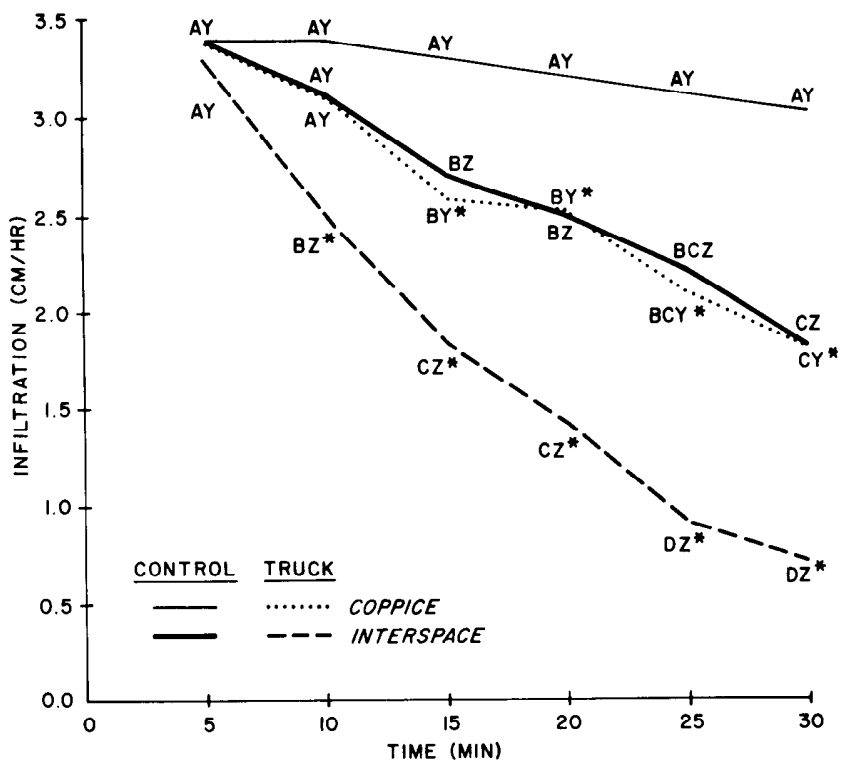

Fig. 2. Infiltration curves for the coppice and gravel-mulched interspace soils on the truck and control treatments at Crystal Springs. Significance of differences over time on each soil within a treatment (letters $A-D$ ); between soils within a treatment (letters $Y-Z$ ); and on each soil between treatments (asterisk) was determined by Duncan's multiple range test at the 5\% level of probability.

(Fig. 2) although the magnitude of difference was less than that at Blue Diamond. Infiltration rate of the gravel-mulched interspace soil decreased over time, however, the decrease was not as rapid as for the corresponding treatment on the gravelembedded interspace surface at Blue Diamond.

The high infiltration rate of undisturbed interspace and coppice soils after 5 minutes is probably due to the volume, size, and continuity of large pores (Musgrave and Holton 1964) and perhaps to cracks between poygons. After these pores and cracks are filled with water, infiltration rate of interspace spoils declines rapidly to a low rate. This rate depends on the movement of water through strata with a small amount of pore space (Musgrave and Holton 1964) that is characteristic of the A horizon of interspace soil with discontinuous, air-filled vesicles. Undisturbed coppice soil would probably have a high infiltration rate for much longer than 30 minutes. Roundy et al. (1978), for example, found an infiltration rate of $7.2 \mathrm{~cm} / \mathrm{hr}$ on a shrub coppice after 1 hour with an application rate of $8.4 \mathrm{~cm} / \mathrm{hr}$ on soil initially at field capacity. Disturbed, dry interspace soil has a high infiltration rate for 5 minutes because of macropore space. Although vesicles in interspace soils are, at least temporarily, destroyed by disturbance, the structureless A horizon slakes and disperses when saturated and many of the macropores may be sealed by fine soil particles (Musgrave and Holton 1964) and infiltration decreases rapidly. In addition, compaction reduces the number and size of macropores. Compaction, loss of structure and macropore space, and mixing of surface and subsurface horizons all contributed to a reduction in infiltration after 10 to 15 minutes on disturbed coppice soil.

The infiltration response over six, 5-minute periods allows a better understanding of sediment production characteristics of soils than does terminal infiltration. Gifford (1968), Jager (1972), and Blackburn (1975) found lower infiltration rates and higher sediment production on soils initially wet than on those initially dry hecause those initially wet, particularly the interspace soil, reach saturation more rapidly. Since interspace soil 
reaches saturation quickly due to low infiltration rate, more time is available during a rainfall event for dispersion and movement of soil particles in runoff water. If saturation and dispersion on interspace soil occur early in a precipitation event, as at Blue Diamond, about 20 to 25 minutes are available for sediment production. If these processes occur late in an event or are of less magnitude, as was the case at Crystal Springs, less time is available for sediment production. These processes did not occur in coppice soil. Coppice soil disturbed by the truck treatment still had characteristics that permitted fairly high infiltration rates through most or all of the test period and the surface soil did not become saturated. If saturation did occur late in the test period, the time for dispersement and movement of soil particles was short. In addition, the structure of this soil contributes to stability against soil movement, even though some runoff may occur (Table 2).

Soil dispersed and suspended in runoff water from simulated rainfall may or may not respresent an erosion loss from similar natural events. The runoff and suspended sediment on the study plots were collected before the sediment could settle. Under natural conditions, such sediment could settle without moving far from its source, since the interspaces are only gently sloping, flat or depressional. Unless the slope is steep and the interspace areas are connected, runoff and suspended sediment usually will not move off-site. Sediment data do represent a potential soil loss if conditions for off-site movement are favorable and the loss would continue over time because vehicle tracks form channels to concentrate water and move sediment. For example, Wilshire and Nakata (1977) measured trail depths of up to $24 \mathrm{~cm}$ about 1 year after an ORV event and after one intense rainstorm. Soil loss from a single trail was estimated at 150 metric tons from a slope between 20 and $26^{\circ}$ and $68 \mathrm{~m}$ long.

Results of this study suggest several ways to reduce damage from off-road-vehicle traffic. Organized and repetitive ORV events should be restricted to areas of minimal environmental importance to prevent extensive watershed damage. Casual ORV use would be least damaging on gentle slopes, on sites with a high proportion of coppice surface soil, and on sites with a gravel-mulch cover of the mineral soil.

\section{Literature Cited}

American Society of Agricultural Engineers. 1971. Compaction of Agricultural Soils. ASAE Monogr. The American Society of Agricultural Engineers. St. Joseph, Mich. $471 \mathrm{p}$.

Blackburn, W.II. 1975. Factors influencing infiltration and sediment production on rangelands in Nevada. Water Resour. Res. 11:929-937.

Blackburn, W.H., R.O. Meeuwig, and C.M. Skau. 1974. A mobile infiltrometer for use on rangelands. J. Range Manage. 27:322-323.

Bury, R.L., R.C. Wendling, and S.F. McCool. 1976. Off-road recreation vehicles-a research summary, 1969-1975. Texas Agr. Exp. Sta. MP-1277. $8+4$.

Davidson, E. and M. Fox. 1974. Effects of off-road motorcycle activity on Mojave Desert vegetation and soil. Madrono 22:381-390.

Gifford, G.F. 1968. Influence of various rangeland cultural treatments on runoff. sediment production, and soil moisture patterns in the big sagebrush type. Eastgate Basin, Nev. PhD Diss., Utah State Univ. 138 p.

Harrison, R. 1976. Environmental effects of off-road vehicles. Engincering Technology. Information System. U.S. Dep. Agr. San Dimas Equipment Development Center, San Dimas, Calif. p. 4-8

Jager, D.J. 1972. The influence of cultural practices and seeded species on overland flow and sediment production from big sage cover type in East Gate Basin. PhD Diss., Univ. of Nevada, Reno. $182 \mathrm{p}$.

Lull, H.W. 1959. Soil compaction on forest and range lands U.S. Dep. Agr., Forest Serv. Misc. Pub. No. 768. Washington, D.C. 33 p.

Lull, H.W. 1964. Section 6. Ecological and silvicultural aspects. In: Handbook of Applied Hydrology. Ven Te Chow (ed.) McGraw Hill Book Co.. New York. p. (6-1-6-30.

Miller, J.F., R.H. Fredrick, and R.J. Tracey. 1973. Precipitation-frequency atlas of the western United States. NOAA Atlas 2. U.S. Dep. Commerce. Nat. Oceanic and Atmospheric Admin. Nat. Weather Serv. Silver Springs. Mld. 43 p.

Musgrave, G.W., and H.N. Holton. 1964. Section 12. Infiltration. In: Handbook of Applied Hydrology. Ven Te Chow (ed.) McGraw Hill Book Co.. New York. p. 12-1-12-20.

Rose, C.W. 1966. Agricultural Physies. Perganon Press, London. $226 \mathrm{p}$.

Roundy, B.A., W.H. Blackburn, and R.E. Eckert, Jr. 1978. Influence of prescribed burning on infiltration and sediment production in the pinyonjuniper woodland, Nevada. J. Range Manage. 31:250-253.

Stebbins, R.C. 1974. Off-road vehicles and the fragile desert. The Amer. Biol. Teacher 36:294-304.

Storey, H.C., R.L. Hobba, and J.M. Rosa. 1964. Section 22. Hydrology of forest lands and rangelands. In: Handbook of Applied Hydrology. Ven Te Chow (ed.) McGraw Hill Book Co.. New York. p. 22-1-22-52.

Vollmer, A.T., B.G. Maza, P.H. Medica, R.B. Turner, and S.A. Bamberg. 1976. The impact of off-road vehicles on a desert ecosystem. EnvironManage. 1:115-129.

Wilshire, H.G., and J.K. Nakata. 1976. Off road vehicle effects on Cali fornia's Mojave Desert. Calif. Geol. 29:123-130

Wilshire, H.G., and J.K. Nakata. 1977. Erosion off the road. Geotimes 22:27

\section{Position Announcements}

Program Administrator at Utah State University. Responsibilities include the in-country administration of a range management sheep and goat research project in Morocco. Coordinate research activities with U.S. and foreign students, scientists, etc. Purchase equipment, establish office, provide reports, etc. BS in range science or related field required. Graduate degree preferred; opportunity exists for pursuit of graduate degree while employed. Permanent residence in Morocco required. Overseas experience in animal production, agriculture, or natural resource management desirable. Fluency in French or Arabic is mandatory. Submit application and credentials by November 15, 1979 to: Dr. John C. Malachek, Small RuminantsCRSP, UMC 52, Utah State University, Logan 84322. An affirmative action/equal opportunity employer.
Extension Range Management Specialist at the University of Wyoming. The position $(75 \%$ extension and $25 \%$ research and/or teaching) is intended to provide statewide leadership in rangeland education and information programs for all range users and managers. A M.S. in range management is requircd. A Ph.D. in range management or associated discipline with a B.S. or M.S. in range management is preferred. A demonstrated knowledge of western rangelands is essential, and communications and public relations skills necessary. Appropriate experience in teaching, research or extension activity is desirable. Contact Dr. Fee Busby, Chairman of Search Committee, Division of Range Management, College of Agriculture, Laramie, Wyo. 8207I. Closing date for applications: November 1 . 1979, or thereafter until an applicant has been selected. 